\title{
The Impact of Service Sectors on Kazakhstan's Economy
}

\author{
Si Thu Han \\ School of Economics and Trade, Hunan University, 410006, Changsha, China \\ Sazzadul Arefin (Corresponding author) \\ School of Economics and Trade, Hunan University, 410006, Changsha, China \\ E-mail: showmikju@gmail.com
}

Khin Myo Swe

School of Economics and Trade, Hunan University, 410006, Changsha, China

Received: September 7, 2018 Accepted: September 21, 2018 Published: October 22, 2018

doi:10.5296/ber.v8i4.13808

URL: https://doi.org/10.5296/ber.v8i4.13808

\begin{abstract}
This paper investigates the influence of service sectors on gross domestic product (GDP) in Kazakhstan. The aim of this paper to determine the role of services such as tourism, finance, transportation, labor and technology in Kazakhstan's economy over 1995-2014. The influence of labor force on GDP is significantly positive while technology has insignificant influence on GDP during the study period. The positive and significant effect of labor force in the case of Kazakhstan is consistent with neoclassical theory.
\end{abstract}

Keywords: Service sector, tourism, finance, transportation, labor, technology, GDP

\section{Introduction}

In comparison with markets of Europe and Asia, Kazakhstan's markets are not big. Service sectors are limited with a relatively small size of markets and the fact that urban population is mainly focused in ten big cities located a long distance from each other. During the Soviet time, retail markets and services markets were not developed for a long time. After achieving independence, the government released new laws and regulations allowing a small sector to start developing. Businessmen started to offer services such as car repairs, building houses and amenities, real estate services, legal services, beauty salon and other kinds of small 
businesses that did not require a big investment.

For Kazakhstan, in this period the proportion of services have grown in all the segments of the economy. In reality, the service sector has grown more than the agricultural and industrial sector. The service sector contributes 57\% of GDP and around 34\% of total employment. Moreover, it has a solid association to other sectors of Kazakhstan's economy. Indispensable inputs to the agricultural and manufacturing sector are delivered by this sector. The export of services in Kazakhstan has grown nearly two-folded over the last decade, extending to $\$ 6.3$ billion in 2016. Although, exports of services in the overall export structure persist comparatively little regardless of the encouraging dynamic forces and in the 2007-2016 period, it ranged from $4.9 \%$ to $14.6 \%$.

The value of the service sector in Kazakhstan's economy and the importance of the service sector is examined in this study. Specifically, the influence of tourism, financial system, transportation, labor, and technology on economic development is primarily stressed in this article.

\section{Literature Review}

In recent years, researchers have come to believe that the service sector in the economy plays an ever-growing role in globalization (Buera and Kaboski, 2012). Mizuno (2005) indicates that income growth and technological innovation are two major factors explaining the development of the service sector. In terms of income growth, the increased consumer demand has expanded the diversity of services (Chadee, 2002). For example, consumer demand has produced more specific requirements for services (Mizuno, 2005). Moreover, in terms of the development of technology, service innovation is supported by the refining and distribution of information during the progress of technology (Nissana et al., 2011).

Previous studies have noted that the service sector generates more employment opportunities for the current generation (Buera and Kaboski, 2012; Wolfmayr, 2012). Employment has dramatically shifted from the manufacturing and agricultural sectors to the service sector in most developed countries in the last two decades (Li and Haynes, 2011). The service sector made a large contribution to the employment figures in OECD countries in 2011 (OECD, 2013b). McKee (2007) claims that the role of services activities in the industrial process assists products moving to final consumers. However, due to the contribution of the service sector to the manufacturing sector being often invisible, it is therefore likely to be underestimated (McKee, 2007).

Ajmair et al. (2016) using ARDL (Autoregressive Distributed Lag) method of estimation for four decades find that in the long run, the important determinants of the service sector output growth in India are government expenditures, foreign trade, population and market size, and in the short run, foreign trade and personal remittances. Jain et al. (2015) examine the impact of different macroeconomic factors on GDP components for the perspectives of India and find that only the service sectors had a significant affect, whereas manufacturing and industry did not. Mujahid and Alam (2014) examines the determinants of the service sector (external debt, gross domestic product per capita, population, FDI, government consumption and 
employ labor force in services for Pakistan's economy for the 35 year period. Applying co-integration technique and vector error correction model, they find that there is a significant effect on FDI, population, investment and consumption on Pakistan's service sector growth.

\section{Methodology}

\subsection{Data and Sample Size}

This research paper is based on the secondary sources of data. Annual time-series data over the period of 1995-2014 are gathered from National Bureau of Statistics of China because of data availability. Moreover, we have also collected data from the Ministry of the national economy of the Republic of Kazakhstan's Committee on Statistics, and secondary data from various published sources such as journals, books, websites, reports, etc.

\subsection{Log-Linear Model}

Basic theory for the Log-linear model is as following;

$$
\log Y_{i}=\alpha+\beta X_{i}+\varepsilon_{i}
$$

According to the theory of long-linear model, the correct explanation of the estimated coefficient $\hat{\beta}$ is given by the one-unit increase in $X$ will always yield a predictable rise in $\log Y_{i}$ of $\hat{\beta}$ unit. This states that the expected value of $Y$ is multiplied by $e^{\widehat{\beta}}$, regarding $Y$ itself. Concerning this the effects of changes in $X$ on $Y$ (unlogged):

- The expected value of $Y$ is multiplied by $e^{\widehat{\beta}}$ for every unit increase in $X$.

- To calculate the influence on $Y$ of additional variation in $X$ other than a rise of one unit, for example $c$-unit, it is required to contain $c$ with exponent. More precisely, to calculate the effect of a $c$-unit raise in $X$ we need to multiply the expected value of $Y$ by $e^{c \widehat{\beta}}$. For example, the effect of a 5-unit raises in $X$ would be calculated as $e^{5 \widehat{\beta}}$.

- When $\hat{\beta}$ takes small values; approximately $e^{\widehat{\beta}} \approx 1+\hat{\beta}$. We can use this method of this approximation for a faster explanation of the coefficients: $100 \times \hat{\beta}$ is the expected percentage change in $Y$ for one unit increase in $X$. For example, if $\hat{\beta}=0.06, e^{0.06} \approx 1.06$, which means a unit alteration in $X$ links to (approximately) an expected percentage raise in $Y$ by $6 \%$.

For our study, this equation will be as shown below.

$\operatorname{LnGDP_{i}}=\alpha_{0}+\alpha_{1} \operatorname{Ln} \operatorname{TOU}_{i}+\alpha_{2} \operatorname{Ln} \operatorname{FIN}_{i}+\alpha_{3} \operatorname{Ln} T R A_{i}+\alpha_{4} \operatorname{Ln} L A B_{i}+\alpha_{5} \operatorname{Ln} T E C_{i}+\varepsilon_{i}(2)$

Where,

- Ln GDP $P_{i}$ logged GDP of Kazakhstan

$-L n T O U_{i}$ stands for logged tourism of Kazakhstan 
$-L n$ FIN $_{i}$ stands for logged financial system of Kazakhstan

-LnTRA $A_{i}$ stands for logged air transport of Kazakhstan

- $L n L A B_{i}$ stands for logged labour force in Kazakhstan

-Ln TEC $C_{i}$ stands for logged technology of Kazakhstan,

Table 1. Descriptive Statistics

\begin{tabular}{|l|c|c|c|c|c|}
\hline Variable & Obs & Mean & Std. dev & Min & Max \\
\hline Gdp & 20 & 8.05285 & 0.8537689 & 7.139 & 9.38 \\
\hline Tourism & 20 & 6.6009 & 0.6844348 & 5.043 & 7.448 \\
\hline Finance & 20 & 3.0645 & 0.7432308 & 1.872 & 4 \\
\hline Trade & 20 & 14.00725 & 0.8031307 & 13.042 & 15.409 \\
\hline Labour & 20 & 15.91259 & 0.0755021 & 15.8328 & 16.0439 \\
\hline Technology & 20 & 7.2922 & 0.1675013 & 6.93 & 7.509 \\
\hline
\end{tabular}

\section{Discussion and Analysis}

The results of ordinary least squares estimations are shown in Table 2 below. The results indicate positive and significant effect of tourism on GDP during the studied period. The variables of the study were taken in log form so we can interpret the respective coefficients of the variables as elasticities. The coefficient of tourism is indicating that a 10 percent increase in tourism will lead to 3.3 percent increase in GDP. If we compare our finding with other studies, we will come to know that tourism coefficient is in such a range, which other studies also found. Our estimation technique is parallel to the elasticity estimate of Georgantopoulos (2012) for Greece and Lee, Chang, \& Chen (2008) panel data estimation of OECD (The Organisation for Economic Co-operation and Development) and non-OECD economics. Georgantopoulos (2012) found that for Greece the tourism elasticity of real GDP is 0.54 . Similarly, Lee, Chang, \& Chen (2008) calculated that for OECD countries, the tourism export elasticity of real GDP varies from 0.13 to 0.36 and for non-OECD countries; it is around 0.17 to 0.61 .

Table 2. The results of the ordinary least squares

\begin{tabular}{|l|c|c|c|}
\hline Independent variables & OLS coefficient & T-value & P-value \\
\hline Tourism & 0.326 & $3.32^{* *}$ & $0.005^{*}$ \\
\hline Finance & 0.285 & $3.92^{* *}$ & $0.002^{*}$ \\
\hline Transportation & 0.07 & 0.86 & 0.403 \\
\hline Labour & 6.01 & $5.08^{* *}$ & $0.000^{*}$ \\
\hline Technology & -0.535 & $-2.49 * *$ & $0.026 * *$ \\
\hline cons & -87.78 & $-4.83 * *$ & 0.000 \\
\hline
\end{tabular}

$\mathrm{R}^{2}=0.9932, \mathrm{R}_{\text {adj }}^{2}=99.08, \mathrm{~N}=20$

Note: $*$ and $* *$ shows significance at $1 \%$ and $5 \%$ respectively

The estimated coefficient of financial development is 0.285 and this is significant at one 
percent. This estimated value of financial development is suggesting that 10 percent increase in financial development will increase GDP by 2.9 percent. This study suggests a positive and significant impact of financial development and economic growth. Our outcome is parallel with numerous prior investigations (Ahmed \& Hasnu, 2009; Guo et al., 2008; Kar \& Pentecost, 2000). This finding disapproves the arguments of researchers such as Brownbridge \& Kirkpatrick, (2000); De Gregorio \& Guidotti, (1995); Demirgüç-Kunt \& Detragiache, (1998, 2000); Gourinchas, Valdes, \& Landerretche, (2001); Kaminsky \& Reinhart, (1999); Schneider \& Tornell, (2004) among others who are of the view that financial development may hinder economic growth. The aforementioned researcher's argument is based on the following; a restricted monitoring power of regulatory institutions, negligent management, the incapability of banks to classify among good and bad ventures throughout investment booms, the existence of an explicit or implicit safeguard against banking catastrophes, the absence of skills in the banking employees, frequent and extensive involvements by the government to steer to moral hazard problems. Thus, we can conclude from this positive effect of financial development that in Kazakhstan, somehow, the authorities managed the above reasons and as a result, the financial development came out positively associated with GDP.

The impact of air transport on GDP is not significant but its coefficient is positive as expected. However, we can claim that tourism is leading to increased GDP in Kazakhstan and this finding of our study is contradicting the existing empirical literature. Marazzo, Scherre, \& Fernandes (2010) directed a groundbreaking investigation on aviation-growth association. The relationship between aviation demand and GDP in Brazil is empirically verified in this study. By using a bi-variate Vector Autoregressive Model and proxy of passenger-kilometer for aviation demand, they found a long-run causation between these two variables. The result indicates a strong positive causation running form GDP to aviation demand and a weaker causation form aviation demand to GDP. Mehmood \& Kiani (2013) using Granger causality, unit root test and cointegration technique investigate the aviation-led growth hypothesis for Pakistan. The result indicates that in contrast to economic development to aviation demand, positive influence of aviation demand to economy is more important. Mehmood \& Shahid (2014) found the positive and significant impact of air transport on economic growth in the case of Czech Republic. Likewise, Anfofum, Zakaree, \& Iluno (2015) found that air transport is positively associated with economic growth in Nigeria.

This study used labor force and technology as control variables. The impact of labor force on GDP is significantly positive whereas technology has an insignificant effect on GDP during the study period 1995-2014. The positive and significant effect of labor force in the case of Kazakhstan is consistent with neoclassical theory.

\section{Conclusion and Recommendations}

As the share of service sector is increasing recently, it draws attention. Examining the output of services, we found that air transport did not have significant effect on economic growth in Kazakhstan but its sign was positive. This result shows that Kazakhstan should take steps to enhance its air transport industry so that it will significantly benefit its economy. The findings 
of the study with respect to financial development yield some policy implications. First, to promote the growth of the country the policymakers should focus on long-run policies for the capital market and in the banking industry. Second, financial development positively affects economic growth in the end. This suggests that such a financial policy needs to be designed to enhance the capacity of the financial intermediaries so they can supply more funds to the economic activity of the Kazakhstan and increase the economic growth. The aim of this paper was to determine the consequence of tourism, financial development and air transport to economic development of Kazakhstan. Furthermore, we used labor force and technology as control variables. The period of the study is from 1995 to 2014 and the time wholly decided because of the availability of the data.

\section{References}

Ahmed, Z., \& Hasnu, S. A. F. (2009). Impact of Financial Development on Economic Growth in Pakistan (1974-2007). FWU J. Soc. Sci., 3, 45-68.

Ajmair, M., Gilal, M. A., \& Hussain, Kh. (2016) Determinants of Services Sector Growth in Pakistan. European Scientific Journal, 12(34), 297-306.

https://doi.org/10.19044/esj.2016.v12n34p297

Anfofum, A., Zakaree, S., \& Iluno, C. (2015). Air transportation development and economic growth in Nigeria. Journal of Economic and Sustainable Development, 6(2).

Brownbridge, M., \& Kirkpatrick, C. (2000). Financial regulation in developing countries. The Journal of Development Studies, 37(1), 1-24. https://doi.org/10.1080/713600056

De Gregorio, J., \& Guidotti, P. E. (1995). Financial development and economic growth. World Development, 23(3), 433-448. https://doi.org/10.1016/0305-750X(94)00132-I

Demirgüç-Kunt, A., \& Detragiache, E. (1998). The determinants of banking crises in developing and developed countries. Staff Papers, 45(1), 81-109.

https://doi.org/10.2307/3867330

Demirgüç-Kunt, A., \& Detragiache, E. (2000). Monitoring banking sector fragility: a multivariate logit approach. The World Bank Economic Review, 14(2), 287-307.

https://doi.org/10.1093/wber/14.2.287

Georgantopoulos, A. G. (2012). Forecasting tourism expenditure and growth: A VAR/VECM analysis for Greece at both aggregated and disaggregated levels. International Research Journal of Finance and Economics, 96(105), 155-167.

Gourinchas, P.-O., Valdes, R., \& Landerretche, O. (2001). Lending booms: Latin America and the world.

Guo, X, Duff, A., \& Hair, M. (2008). Service quality measurement in the Chinese corporate banking market. The International Journal of Bank Marketing, 26(5), 305-327. https://doi.org/10.1108/02652320810894389

Jain, D., Nair, K. S., \& Jain, V. (2015). Factors Affecting GDP (Manufacturing, Services, 
Industry): An Indian Perspective. Pune Annual Research Journal of Symbiosis Centre for Management Studies, 3, 38-56.

Kaminsky, G. L., \& Reinhart, C. M. (1999). The twin crises: the causes of banking and balance-of-payments problems. American Economic Review, 89(3), 473-500.

https://doi.org/10.1257/aer.89.3.473

Kar, M., \& Pentecost, E. J. (2000). Financial development and economic growth in Turkey: further evidence on the causality issue. Universitäts-und Landesbibliothek Sachsen-Anhalt.

Lee, C.-C., Chang, C.-P., \& Chen, P.-F. (2008). Energy-income causality in OECD countries revisited: The key role of capital stock. Energy Economics, 30(5), 2359-2373.

https://doi.org/10.1016/j.eneco.2008.01.005

Marazzo, M., Scherre, R., \& Fernandes, E. (2010). Air transport demand and economic growth in Brazil: A time series analysis. Transportation Research Part E: Logistics and Transportation Review, 46(2), 261-269. https://doi.org/10.1016/j.tre.2009.08.008

Mehmood, B., \& Kiani, K. (2013). An inquiry into nexus between demand for aviation and economic growth in Pakistan. ACADEMICIA: An International Multidisciplinary Research Journal, 3(10), 200-211.

Mehmood, B., \& Shahid, A. (2014). Aviation demand and economic growth in the Czech Republic: cointegration estimation and causality analysis. Statistika: Statistics and Economy Journal, 94(1), 54-63.

Mujahid, H. \& Alam, Sh. (2014). Service sector as an engine of growth: empirical analysis of Pakistan. Asian Economic and Financial Review, 4(3), 377-386.

Schneider, M., \& Tornell, A. (2004). Balance sheet effects, bailout guarantees and financial crises. The Review of Economic Studies, 71(3), 883-913.

https://doi.org/10.1111/j.1467-937X.2004.00308.x

\section{Copyright Disclaimer}

Copyright for this article is retained by the author(s), with first publication rights granted to the journal.

This is an open-access article distributed under the terms and conditions of the Creative Commons Attribution license (http://creativecommons.org/licenses/by/3.0/). 